\title{
Impact of COVID-19 on Pregnancy and Maternal Health: An Update
}

\author{
Fauziah Jummaat ${ }^{1, *}$, Esam Bashir Yahya ${ }^{2, * 0}$, A.S. Adnan ${ }^{1}$, Atty Sofea A.K. ${ }^{3}$
}

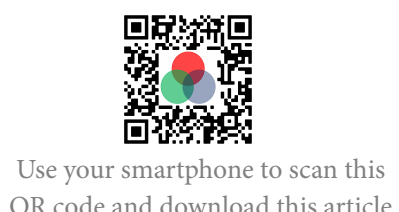

QR code and download this article

${ }^{1}$ Management Science University Medical Centre, University Drive, Off Persiaran Olahraga, Section 13, 40100 Shah Alam, Selangor, Malaysia

${ }^{2}$ School of Industrial Technology, Universiti Sains Malaysia, Penang 11800, Malaysia

${ }^{3}$ Hospital Seberang Jaya, Jalan Tun Hussein, Seberang Jaya, Permatang Pauh, 13700, Penang, Malaysia

\section{Correspondence}

Fauziah Jummaat, Management Science University Medical Centre, University Drive, Off Persiaran Olahraga, Section 13, 40100 Shah Alam, Selangor, Malaysia

Email: drfauziahjummaat@gmail.com

\section{Correspondence}

Esam Bashir Yahya, School of Industrial Technology, Universiti Sains Malaysia, Penang 11800, Malaysia

Email: essam912013@gmail.com

\section{History}

- Received: Sep 06, 2021

- Accepted: Oct 16, 2021

- Published: Oct 30, 2021

DOI : 10.15419/bmrat.v8i10.701

\section{Check for updates}

\section{Copyright}

(c) Biomedpress. This is an openaccess article distributed under the terms of the Creative Commons Attribution 4.0 International license.

\begin{abstract}
The current pandemic caused by the novel coronavirus disease 2019 (COVID-19) is spreading at an accelerated rate globally. Global concerns were raised following its discovery in December 2019, as previous similar diseases. Diseases such as the severe acute respiratory syndrome-related coronavirus (SARS-CoV) and the Middle East respiratory syndrome-related coronavirus (MERS-CoV) are known to lead to adverse outcomes in pregnant women and those in early maternal stages, with significantly higher rates of complication and mortality compared to other groups of individuals. The anatomical, physiological, and immunological changes that occur during pregnancy lead to higher risks associated with respiratory infections for pregnant women, as they can directly affect the well-being of pregnant women and infants. Vertical transmission of COVID-19 from mother to child was a concern, as such transmission could endanger a child. Three mechanisms of vertical transmission have been suggested: intrauterine transmission, placental blood transmission, and intrapartum transmission. This review discusses the impact and pathogenicity of COVID-19 on the well-being of pregnant and early maternal women, both the clinical aspect, health aspects, and diagnostic and therapeutic options. It will also discuss the adverse outcomes among pregnant women and newborn infants who contract the disease and the different mechanisms of vertical transmission from infected mother to child. The diagnostic and therapeutic approaches of COVID19 that have been recently used have also been highlighted, in addition to the challenges faced by pregnant women who have contracted the virus during the pandemic.
\end{abstract}

Key words: COVID 19, health care, infection, maternal, pandemic, pregnancy, vertical transmission

\section{INTRODUCTION}

The novel coronavirus disease 2019 (COVID-19) was first reported in Wuhan city, Hubei province, China, in late December $2019^{1}$. The causative agent of this novel disease was identified on January $7^{\text {th }} 2020$, from throat swab samples taken from patients by the Chinese Centre for Disease Control. They subsequently named the disease based on its symptoms, severe acute respiratory syndrome-related coronavirus 2 (SARS-CoV-2) ${ }^{2,3}$. After a few months, the World Health Organisation (WHO) named the disease COVID-192. To date, most COVID-19 infected individuals have developed mild symptoms that persist for periods ranging from days to weeks, such as fever, malaise, sore throat, dry cough, and shortness of breath ${ }^{4,5}$. The majority of patients have spontaneously recovered without the need for special treatment. However, some patients have developed serious complications, including septic shock, organ failure, severe pneumonia, pulmonary edema, and acute respiratory distress syndrome ${ }^{5-7}$. Various global studies have consistently shown that more than $80 \%$ of the total number of COVID-19-related deaths have been reported among older age individuals who suffer from other chronic diseases. Only $0.1 \%$ of deaths have occurred in individuals under 19 years of age $e^{8-10}$.

Several physiological and immunological changes occur in a woman's body during pregnancy. These changes may predispose pregnant women towards significant health complications from respiratory infections, such as an increased risk of miscarriage, preterm birth, or even fetal mortality and morbidity ${ }^{10-12}$. Worldwide concerns were raised following the first reported cases of COVID-19, as previous similar diseases such as the severe acute respiratory syndrome-related coronavirus (SARS-CoV) and the Middle East respiratory syndrome-related coronavirus (MERS-CoV) were known to lead to adverse outcomes for pregnant women. Namely, pregnant women who contracted these diseases had greater mortality rates than non-pregnant individuals ${ }^{13-15}$. On March $11^{\text {th }}, 2020$, WHO characterized COVID19 as a global pandemic. This decision was based on the previous coronavirus outbreaks that led to the loss of millions of lives, such as the Spanish flu (H1N1), 
which resulted in the highest number of deaths (approximately 50 million worldwide) and the Asian flu (H2N2), which resulted in between $1-4$ million deaths ${ }^{16,17}$. Figure 1 presents the recent pandemics caused by coronaviruses worldwide, with the approximate number of deaths caused by each. Few previous studies have classified pregnant women as not significantly immune-compromised ${ }^{18}$. Various immunological changes have recently been found to occur during pregnancy, which may, therefore, increase the susceptibility of pregnant women to certain intracellular pathogens, such as COVID-19 ${ }^{19,20}$. This, in turn, may render them more susceptible to infection and increase the risk of them being adversely affected when compared to the non-pregnant individuals.

Numerous research papers have been published regarding the clinical manifestation, characteristics, and symptoms of COVID-19, as well as on therapeutic clinical trials ${ }^{21-24}$. Systematic reviews examining its effect on women who are pregnant or in early maternal stags also have been published ${ }^{25,26}$. However, most have been limited in the number of patients able to be examined due to the recency of the pandemic. Della Gatta et al. ${ }^{14}$ reviewed the clinical outcomes reported in six studies that involved 51 pregnant women infected with COVID-19. KarimiZarchi et al. ${ }^{27}$ examined the risk of COVID-19 being vertically transmitted from infected mothers to fetuses using published data in articles and official websites up till March 2020. Other reviews have further discussed the possibility of COVID-19 vertical transfer with controversial results ${ }^{27-31}$. The current review discusses the impact of COVID-19 on pregnant individuals, specifically in relation to its clinical manifestation and adverse maternal and fetal outcomes compared to non-pregnant individuals. Recent studies examining the mechanisms of vertical transmission of COVID-19 from infected mothers to newborns and/or fetuses have been used, in addition to the studies examining the placental pathology of infected mothers. Diagnostic approaches for COVID19 and the therapeutic options that have been used are also highlighted, as well as the challenges pregnant women have faced during this pandemic.

\section{CLINICAL CHARACTERISTICS OF PREGNANT WOMEN INFECTED WITH COVID-19}

All genders and ages are susceptible to COVID19 infection, including pregnant women and newborns ${ }^{32}$. The clinical manifestation of COVID-19 among pregnant women has been characterized by mild and sometimes severe upper respiratory tract symptoms, such as dry cough and chest tightness, as well as other, less commonly observed symptoms such as high fever, fatigue, dyspnea, diarrhea, and headache ${ }^{33,34}$. Typically, severe upper respiratory tract infections are confirmed using chest computed tomography (CT images). China's case-control study revealed that $94 \%$ of pregnant women with confirmed COVID-19 infections had severe infections ${ }^{35}$. However, another study reported that most pregnant women with COVID-19 were asymptomatic upon admission to hospital, and none experienced any severe respiratory failure during their hospital stay ${ }^{36}$. This suggests that different stages of pregnancy and different immune responses in each case may affect the presenting symptoms of COVID-19 in pregnant women. A study by Yang et al. ${ }^{37}$ found that COVID-19 positive cases did not show any expectoration, dyspnea, or myalgia. However, CT images of their pulmonary systems resembled COVID-19 pneumonia. Furthermore, pleural effusion was significantly higher among COVID-19 positive cases in pregnant women compared to non-pregnant women. Figure 2 presents a summary of the symptoms and potential complications that can occur in COVID-19-infected pregnant women.

\section{Adverse outcomes of COVID-19 among pregnant women}

COVID-19 infection has been associated with maternal hypercoagulability and pyrexia (cytokine storm), which can lead to increased infarction, placental intervillous thrombosis, and maternal hypoxia ${ }^{38,39}$. However, evidence regarding fetal morbidity and mortality due to COVID-19 infection is still limited. Still, maternal changes secondary to COVID19-infected pregnant women may lead to hypoxia and fetal heart rate changes ${ }^{38}$. In two recent studies by Zhu et al. ${ }^{40}$ and Chen et al. ${ }^{41}$, it was found that in eighteen middle-aged pregnant women infected with COVID-19, all had at least one or more common clinical symptoms, such as a dry cough, fever, sore throat, chest pain, or diarrhea. A significant variation in newborn birth weight was observed in these mothers, with weights ranging from $1520 \mathrm{~g}$ to $3820 \mathrm{~g}$. The authors reported that more than half of the pregnant women in the studies had preterm deliveries, which is a higher rate than seen in non-infected pregnant women. They also reported other obstetrical complications in these women, such as preeclampsia, irregular contractions, premature rupture of membrane, and stillbirth, indicating early pregnancy intervention. Anatomical 


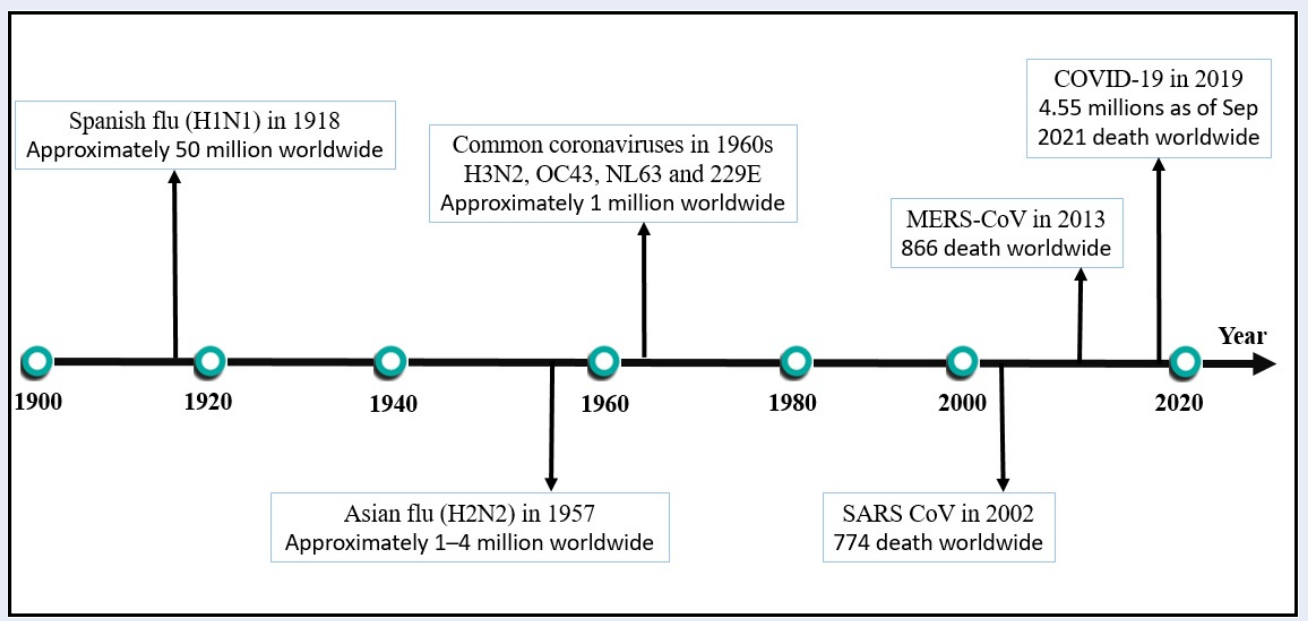

Figure 1: A time-line of global death caused by different coronavirus pandemics, as of September 2021. ht tps://doi.org/10.6084/m9.figshare.16909204.v1

\section{COVID-19 symptoms and complications during pregnancy}

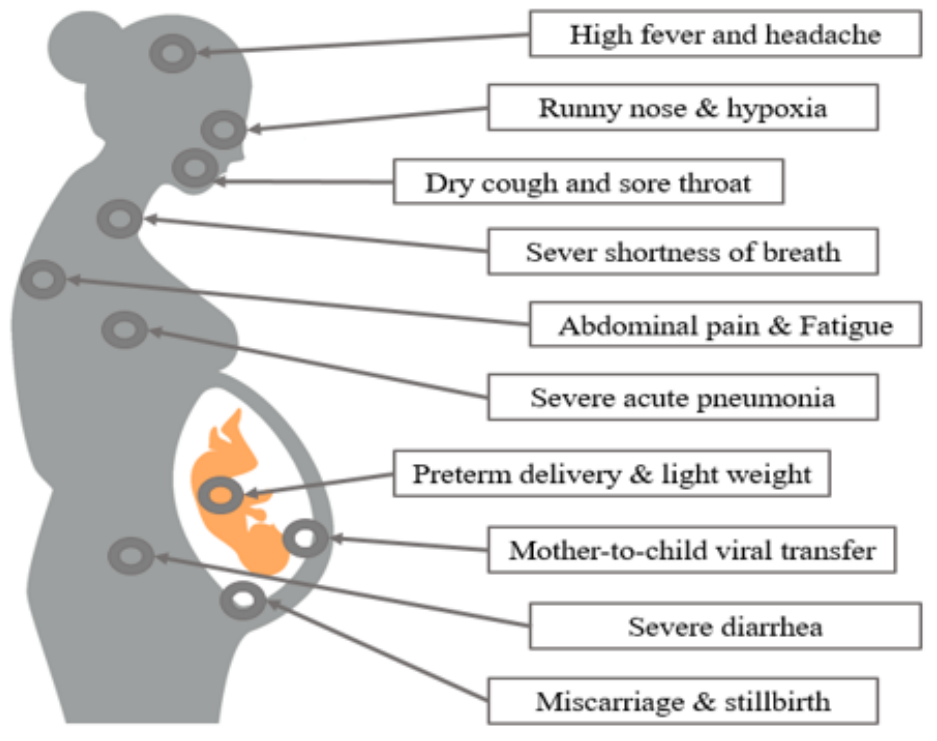

Figure 2: Summary of COVID-19 symptoms and complications during pregnancy. The virus can affect both mother and unborn child, causing serious adverse outcomes. https://doi.org/10.6084/m9.figshare.16909207.v1

changes during pregnancy, such as diaphragm elevation, increased thoracic cage transverse diameter, decreased maternal tolerance to hypoxia, put pregnant women at a higher risk from respiratory infections ${ }^{42}$. Baud et al. ${ }^{43}$ observed contractive abdominal pain and fever among pregnant women suffering from COVID-19. Fetal distress has also been reported in pregnant women; however, it remains unclear whether it is caused by the COVID-19 infec- tion or pneumonia ${ }^{14}$. A study from Iran reported that, out of nine COVID-19 infected pregnant women who were displaying initial symptoms of pneumonia, seven women died following a few days of hospitalization. Of the two who survived, one of them was critically sick and ventilator-dependent, while the other was successfully cured after prolonged hospitalization $^{44}$. Table 1 summarizes the maternal outcomes of COVID-19-infected pregnant women and 
Table 1: Maternal and fetal effects of COVID-19 reported in various studies

\begin{tabular}{|c|c|c|c|c|}
\hline Study & Location & $\begin{array}{l}\text { Number of } \\
\text { patients }\end{array}$ & Maternal effects & Fetal effects \\
\hline Blitz et al. ${ }^{45}$ & USA & $\begin{array}{l}462 \text { pregnant } \\
\text { women }\end{array}$ & $\begin{array}{l}\text { Preterm births, elevated inflam- } \\
\text { matory markers, tachycardia, } \\
\text { lymphopenia, and hypoxia }\end{array}$ & $\begin{array}{l}\text { Preterm babies and COVID-19 } \\
\text { positive babies }\end{array}$ \\
\hline Yan et al. ${ }^{46}$ & China & $\begin{array}{l}116 \text { pregnant } \\
\text { women }\end{array}$ & $\begin{array}{l}\text { Increase in spontaneous preterm } \\
\text { birth. }\end{array}$ & $\begin{array}{l}\text { Severe neonatal asphyxia and } \\
\text { neonatal death }\end{array}$ \\
\hline Sayeed et al. ${ }^{47}$ & Bangladesh & $\begin{array}{l}68 \text { pregnant } \\
\text { women }\end{array}$ & $\begin{array}{l}\text { Dyspnea, myalgia, and increased } \\
\text { rate of abortion }\end{array}$ & $\begin{array}{l}\text { Preterm babies, neonatal pneu- } \\
\text { monia, hyperbilirubinemia, } \\
\text { and fetal death }\end{array}$ \\
\hline $\begin{array}{l}\text { Elshafeey } \\
\text { et al. }{ }^{48}\end{array}$ & Global & $\begin{array}{l}385 \text { pregnant } \\
\text { women }\end{array}$ & $\begin{array}{l}\text { Mechanical ventilation depen- } \\
\text { dency, increases in abortion and } \\
\text { maternal mortality }\end{array}$ & $\begin{array}{l}\text { Neonatal death, preterm birth, } \\
\text { intrauterine fetal distress, and } \\
\text { COVID-19 positive babies }\end{array}$ \\
\hline Savasi et al. ${ }^{49}$ & Italy & $\begin{array}{l}77 \text { pregnant } \\
\text { women }\end{array}$ & $\begin{array}{l}\text { Increased pregestational body } \\
\text { mass indexes and abnormal } \\
\text { respiratory and heart rates }\end{array}$ & $\begin{array}{l}\text { COVID-19 infection in the } \\
\text { early postpartum period }\end{array}$ \\
\hline Smith et al. ${ }^{\mathbf{5 0}}$ & Global & $\begin{array}{l}92 \text { pregnant } \\
\text { women }\end{array}$ & $\begin{array}{l}\text { Preterm births, fetal distress, and } \\
\text { fetal intensive care and ventilation } \\
\text { requirement }\end{array}$ & $\begin{array}{l}\text { Signs of vertical transmission, } \\
\text { low birth weight, and require- } \\
\text { ment for NICU admission }\end{array}$ \\
\hline $\begin{array}{l}\text { Capobianco } \\
\text { et al. }^{51}\end{array}$ & China & $\begin{array}{l}13 \text { research } \\
\text { studies }\end{array}$ & $\begin{array}{l}\text { ICU admission and preterm in- } \\
\text { fants pooled proportion }\end{array}$ & $\begin{array}{l}\text { Pneumonia, infected infants } \\
\text { pooled proportion, and respi- } \\
\text { ratory distress syndrome }\end{array}$ \\
\hline $\begin{array}{l}\text { Zaigham \& } \\
\text { Andersson }^{52}\end{array}$ & Global & $\begin{array}{l}108 \text { pregnant } \\
\text { women }\end{array}$ & $\begin{array}{l}\text { Lymphocytopenia, elevated CRP, } \\
\text { and ICU admission }\end{array}$ & $\begin{array}{l}\text { Intrauterine death and in- } \\
\text { trauterine growth restriction }\end{array}$ \\
\hline Diriba et al. ${ }^{53}$ & Global & $\begin{array}{l}879 \text { pregnant } \\
\text { women }\end{array}$ & $\begin{array}{l}\text { Preterm birth, miscarriage, } \\
\text { preeclampsia, and fetal growth } \\
\text { restriction }\end{array}$ & $\begin{array}{l}\text { Neonatal asphyxia, apgar score, } \\
\text { ICU admission, and perinatal } \\
\text { death }\end{array}$ \\
\hline
\end{tabular}

their neonates observed in various studies.

\section{Fetal outcomes in COVID-19 infections}

The first reported newborn infant delivered by a COVID-19 positive mother was on February $5^{\text {th }} 2020$. This was announced by the official Xinhua news agency. The infant had no fever or cough and stable vital signs but had observable shortness of breath, unusual chest radiographs, and abnormalities in liver function ${ }^{\mathbf{5 4 5 5}}$. Dashraath et al. ${ }^{\mathbf{5 6}}$ observed numerous adverse neonatal outcomes from COVID-19 positive mothers, including fetal distress (43\%), preterm birth (39\%), intrauterine growth restriction $(10 \%)$, perinatal death $(7 \%)$, and miscarriage $(2 \%)$. These outcomes were mainly dependent on the stage and complications during the pregnancy; increased effects of COVID-19 on pregnant women led to more adverse fetal outcomes. In their systematic review, Yang et al. ${ }^{25}$ reported that other COVID-19-related adverse fetal and neonatal outcomes had been observed, including fetal distress, stillbirth, neonatal death, and neonatal asphyxia. In a different study, the prognosis of infected infants was reported to be good, although preterm births with significantly low birth weights were observed, and many newborns suffered intrauterine fetal distress and respiratory distress syndromes. Some newborns were immediately admitted to neonatal intensive care units as they had neonatal pneumonia, which requires neonatal mechanical ventilation ${ }^{48}$. The placenta has been reported to execute and orchestrate the pathways of fetal growth. Some studies have revealed the ability of COVID-19 to induce placental gross pathological alterations ${ }^{57}$. Vascular abnormalities that occur in the placentas of infected mothers included fetal vascular malformations and malperfusion in $50 \%$ of pregnancies ${ }^{\mathbf{5 8 , 5 9}}$. Chen et al. ${ }^{33}$ reported an increased incidence of spontaneous and induced abortions among infected mothers, suggesting the potential risks of abortion, premature gestational loss, and congenital defects in neonates in infected mothers. 
Mechanisms of vascular damage of COVID19 among pregnant women

The COVID-19 nucleocapsid proteins contain a highly complex RNA. However, as is typical of coronaviruses, the nucleocapsid is surrounded by a membrane containing three proteins: spike protein, small membrane protein $\mathrm{E}$, and membrane protein $\mathrm{M}^{\mathbf{6 0}}$. When the virus attaches to the respiratory tract, cell entry occurs via two pathways. One pathway is the direct plasma membrane route, which involves the transmembrane serine protease 2 and is used by most viruses ${ }^{61}$. The other pathway is through viral spike proteins, which tightly attach to the ACE2 receptor (angiotensin-converting enzyme 2) and release the viral genome into the host cell. The viral genome is translated inside the host cell, replicating and producing more RNA genomes and viral proteins, and consequently, continuing the life cycle of the virus ${ }^{62}$. Narang et al. ${ }^{63}$ reported that the ACE2 enzyme plays an essential role in the conversion of many angiotensin compounds, including the conversion of angiotensin I to angiotensin-(1-9) and angiotensin II to angiotensin(1-7), which causes antithrombotic, vasodilatory, and anti-inflammatory effects ${ }^{64}$. During pregnancy, a women's hormonal profile changes, increasing the levels of renin-angiotensin-aldosterone system compounds, including ACE2.7. These changes put pregnant women at a greater risk of contracting and suffering adverse outcomes from COVID-1965. Systemic vasodilatory responses are maintained in pregnant women to balance their blood pressure. This occurs through the conversion of angiotensin II, resulting in increased levels of angiotensin-(1-7) ${ }^{66}$. Garovic et al. ${ }^{67}$ reported that $3.5 \%$ of all pregnancies suffer from the pregnancy-specific hypertensive disorder, preeclampsia. Preeclampsia is characterized by multisystem involvement due to the loss of angiotensin regulation leading to imbalanced blood pressure. COVID-19 has been reported to downregulate the ACE2 receptor after it binds to it ${ }^{68}$. This downregulation potentiates renin-angiotensin-aldosterone system abnormalities if the infection occurs during the pregnancy, and leads to an increase in the conversion of angiotensin II relative to the decreased angiotensin(1-7) levels that are present in preeclampsia ${ }^{69}$. Coagulation abnormalities and endothelial cell dysfunction are two other common mechanisms shared between COVID-19 and preeclampsia, both of which cause vascular damage. Endothelial cells are known to express ACE2 receptors. Infection with COVID-19 during pregnancy may significantly mimic and/or initiate microvascular dysfunction of endothelial cells by causing endotheliitis. Endotheliitis has been reported to cause systemic inflammation and microcirculatory dysfunction. Some studies have reported that the induction of endothelial cell injury via an immune cell-mediated response is characterized by the resulting vasoconstriction and ischemia ${ }^{69-71}$. Cattaneo et al. ${ }^{72}$ reported that COVID-19 patients recorded high rates of stroke, deep vein thrombosis, and pulmonary embolism due to a pro-coagulopathic state. Pregnant women with COVID-19 can be particularly prothrombotic due to coagulation abnormalities resulting from hormonal alteration, which may potentiate a hypercoagulable state ${ }^{63}$. Thus, pregnant women are significantly susceptible compared to non-pregnant women for invasive infection with COVID-19.

\section{The immune responses to COVID-19 in pregnancy}

Since the outbreak of COVID-19, numerous infections have been reported among pregnant women ${ }^{73}$. It is known that during pregnancy, the female immune, respiratory, circulatory, secretory, reproductive, and endocrine systems undergo significant physiological changes, making them more sensitive to viral infections such as COVID-19 ${ }^{55,74,75}$. During pregnancy, the immune system faces significant challenges regarding establishing and maintaining tolerance to the growing allogeneic fetus while concurrently responding to potential generated cancers and/or microbial infections ${ }^{\mathbf{2 0}, 76}$. COVID-19 infected mothers have been confirmed to be at a higher risk of developing more severe respiratory complications ${ }^{27}$. Many studies have confirmed the ability of COVID-19 to alter immune responses, particularly at the pregnancy and maternal-fetal interface, which directly affects the well-being of pregnant women and infants ${ }^{77-79}$.

Interestingly, the cytokine profiles in non-pregnant COVID-19 infected women have been extrapolated to account for the different severities of the disease in affected pregnancies. Preferential activation of Th1 immunity has been observed among pregnant women infected with COVID-19. This activation has been found to lead to a marked increase in the production of pro-inflammatory cytokines (IFN $\gamma$, IL-6, IL$1 \beta$ and IL-12) for more than 14 days following the onset of disease, which, in turn, causes extensive lung damage ${ }^{34}$. The activation of $\mathrm{Th}_{1}$ and $T \mathrm{~h}_{2}$ cells during COVID-19 infection leads to a significant increase in IL-6 levels and the Th1 response. This activation is associated with an increased mortality risk, particularly 
among pregnant women ${ }^{34}$. The natural immune response to the placenta and its tropism increase pregnant womens' susceptibility to COVID-19 and other certain infectious diseases ${ }^{\mathbf{8 0}}$. Decreased numbers and activity of natural killer cells (NK) and T lymphocytes in the late stage of gestation have been reported to affect the clearance rate of the viruses, favoring the onset of viral infection ${ }^{55}$. Tsafaras et al. ${ }^{81}$ reported that dysregulation of many immune factors, such as the complement cascade and several cytokines, as a result of viral infection may have deleterious consequences to fetuses and newborns, particularly in relation to brain development and function. More importantly, immature immune systems put fetuses and newborns at a high risk of developing infections after birth $^{82}$.

\section{VERTICAL TRANSMISSION OF COVID-19 FROM MOTHER-TO-CHILD}

The transmission method of COVID-19 from mother to fetus has not yet been well-established ${ }^{83}$. The possibility of vertical transmission has always been of great concern to obstetricians and neonatologists. Karimi et al. ${ }^{27}$ collected data from published research articles and hospitals' official websites at the beginning of the pandemic and found that no COVID19 infection had been detected in neonates or placentas. The authors reported two deaths of mothers after delivery from COVID-19-related respiratory complications. However, recent studies have reported three potential mechanisms of vertical transmission of the virus from mother to fetus, namely intrauterine transmission ${ }^{\mathbf{8 4}}$, placental blood transmission ${ }^{85}$, and intrapartum transmission ${ }^{86}$. Komine-Aizawa et al. ${ }^{87}$ suggested four mechanisms for COVID-19 to cross the placental barrier, namely passaging from the maternal circulation to extravillous trophoblasts (placental cells) passaging through maternal immune cells, direct infection of syncytiotrophoblasts, and ascending infection through the maternal vaginal tract. Intrauterine transmission occurs during pregnancy at any time ${ }^{88}$. Multiple findings suggest the possibility of intrauterine vertical transmission of COVID-19. Some studies have reported positive real-time PCR (RT-PCR) testing for COVID-19 of a neonate directly after birth, the elevation of specific immunoglobulins ( $\operatorname{Ig} \mathrm{M}$ ), and the early onset of symptoms in neonates $\mathbf{8 9 , 9 0}$. However, other studies have revealed the opposite. Elósegui et al. ${ }^{91}$ found no evidence to suggest the possibility of COVID-19 passage from mother to amniotic fluid. The same conclusion has been drawn in many other studies ${ }^{\mathbf{9 2}} \mathbf{9 4}$. Intrapartum transmission or transmission of COVID-19 from mother to baby during or directly after delivery have been reported to occur, despite initial negative test results, due to the incubation period of the virus being 14 days ${ }^{95}$. Intrapartum or early postnatal infection have also been reported to possibly occur through direct exposure of the newborn to COVID19 infected maternal blood or other secretions ${ }^{96}$. Placental blood transmission of COVID-19 may occur at different stages of pregnancy, which will result in different impacts depending on the developmental stage of the fetus ${ }^{97}$. In a recent study by Schwartz et al. ${ }^{\mathbf{8 9}}$, it was suggested that the diagnosis of intrauterine transplacental COVID-19 among infected mother-neonate dyads should be based on the identification of COVID-19 in fetal-derived cells, using advanced techniques such as in situ hybridization, nucleic acid-based technique, or immunohistochemistry. The authors demonstrated that COVID-19 was able to enter the placenta and pass to the fetus prior to delivery. These findings confirm placental viral infection in different neonates.

\section{Placental pathology in COVID-19-infected mothers}

The RNA of COVID-19 has been proven to transfer through placental tissues, leading to adverse effects for developing fetuses ${ }^{98}$. Numerous studies have confirmed the potential transmission of COVID-19 through the placenta. In a study by Yang et al. ${ }^{99}$, evidence of COVID-19 infection was found in nine out of 83 neonates. Zaigham et al. ${ }^{52}$ reviewed 18 research articles and found one neonatal death and one intrauterine fetal demise that resulted from placental pathology. Vascular malperfusion has been reported to be the most common placental pathology among COVID-19-positive mothers. Mulvey et al. ${ }^{100}$ investigated the placentas of five COVID-19 infected mothers who delivered at term and reported that all showed fetal vascular malperfusion and multiple thromboses. The evidence of thrombosis in all five mothers was seen in larger vessels in the fetal circulation. The presence of the spike protein and RNA of COVID-19 within the placentas of infected mothers was rare, indicating that COVID-19 did not directly infect the placentas, and thus the observed effects of thrombosis were a result of the systemic effects of the virus ${ }^{100}$. Maternal and fetal tissues are known to be separated by syncytiotrophoblast layers, which act as a physical barrier against the vertical transmission of many pathogens, including viruses. However, 
Baergen et al. ${ }^{\mathbf{5 8}}$ reported nine cases of fetal vascular malperfusion among 20 cases of COVID-19 infected mothers.

Similarly, Shanes et al. ${ }^{101}$ examined 16 placentas of COVID-19 infected mothers and reported that in the 15 third-trimester placentas, fetal vascular malperfusion and maternal vascular malperfusion were observed in 12 of them. In contrast, some studies examining other newly emergent viral diseases, such as the Zika virus, have found a lack of placental pathology except for some cases that report chorionic villous stromal macrophages hyperplasia (Hofbauer cells) ${ }^{102,103}$. Focusing on placental features can significantly contribute to understanding the impacts of COVID-19 infection on maternal and fetus wellbeing. Due to the limited number of studies and patients, it is important to further investigate the histology, immunohistochemistry, and molecular genetics of the placenta of COVID-19 infected women who are in the later stages of pregnancy.

\section{DIAGNOSTICS AND THERAPEUTIC OPTIONS FOR COVID-19 IN PREGNANCY}

The COVID-19 pandemic spread globally at a rapid pace, causing a necessary and rapid adjustment in the fields of gynecology and obstetrics. RT-PCR has been described as the best diagnostic approach for detecting COVID-19 infection ${ }^{104}$. However, this technique is highly affected by the quality of the sampling process, where low-quality samples may not give accurate results ${ }^{19}$. Ali et al. ${ }^{105}$ used RT-PCR for scanning 11 asymptomatic pregnant women from China, who all tested negative for COVID-19. The authors also performed a CT scan and serum antigen-antibody (IgM and IgG) titers, revealing typical abnormalities related to COVID-19, indicating that infection lesions and ground-glass opacity had resulted from viral pneumonia. The authors also observed elevation in IgM and IgG antibody levels in the serum of patients that were determined to be pregnant following the CT scan, which is another indication of COVID19 infection. This suggests that both CT imaging and serum antigen-antibody profiles are accurate markers for COVID-19 diagnosis, particularly in asymptomatic pregnant women. Consistency comparisons between CT and RT-PCR have been carried out. Ai et al. ${ }^{106}$, who reported similar results, suggested the requirement for longer RT-tests for COVID-19 detection. Zhang et al. ${ }^{107}$ suggested using serum antigenantibody (IgM and IgG) for COVID-19 detection as a more accurate approach that is not limited by lowquality sampling like RT-PCR. Donders et al. ${ }^{108}$ suggested that the threshold for frequent testing of pregnant women with COVID-19 symptoms should be lowered to provide more regular follow-ups for both fetal and maternal complications. Clinical assessment determines and decides the requirement for hospitalization in pregnant patients while awaiting the test results. Numerous drugs have been used for COVID19 treatment in both pregnant and non-pregnant patients. Table 2summarizes some of the most commonly used drugs.

\section{CHALLENGES FACING PREGNANT WOMEN DURING THE COVID-19 PANDEMIC}

COVID-19 is a highly contagious disease that can be rapidly spread from symptomatic and asymptomatic patients ${ }^{118,119}$. It has been confirmed that this disease has the ability to cause serious health impacts in both pregnant women and their newborn fetuses. WHO recommends frequent COVID19 testing during pregnancy via RT-PCR testing ${ }^{\mathbf{1 2 0}}$. A high proportion of COVID-19 infections worldwide have been caused by asymptomatic patients ${ }^{\mathbf{1 3}}$. Thus, implementing strict infection control measures as well as conducting universal screening of all pregnant women is critical for early diagnosis and the prevention of any further risk to both mothers and neonates. The Royal College of Obstetricians \& Gynaecologists and the American College of Obstetricians \& Gynecologists both recommend that pregnant women in all stages of pregnancy should take preventive measures, as they are considered to be at high risk of developing complications compared to other populations. Both colleges recommend wearing masks, washing hands with effective disinfectant, strictly maintaining social distancing, and undergoing frequent COVID-19 testing in order to prevent transmission of the disease $\mathbf{1 1 8}^{\mathbf{1 1 2 1}}$. It is still uncertain whether COVID-19 can be transmitted via breast milk. However, Groß et al. ${ }^{122}$ examined milk from two COVID-19 infected nursing mothers and detected COVID-19 in one mother's breast milk, and suggested that the COVID-19 loads in that mother's breast milk may have been noticeably higher than detected. The same authors detected COVID-19 RNA in the breast milk of one of the infected mothers, who displayed mild COVID-19 symptoms. The newborn was confirmed to be positive for COVID-19 newborn following breastfeeding, despite health precautions, such as wearing a mask and nipple and surrounding area sanitization, being followed. This suggests that there is a high potential for COVID-19 to 
Table 2: Therapeutic drugs used for COVID-19 treatment in infected pregnant and postpartum women

\begin{tabular}{|c|c|c|c|}
\hline Drug & Mechanism of action & Effect and safety during pregnancy & References \\
\hline $\begin{array}{l}\text { Hydroxy- } \\
\text { chloroquine }\end{array}$ & $\begin{array}{l}\text { Reduces inflammatory } \\
\text { response and interferes } \\
\text { with the synthesis of } \\
\text { ACE2 receptor }\end{array}$ & $\begin{array}{l}\text { Considered safe during pregnancy, as it re- } \\
\text { duces temperature, promotes pneumonia re- } \\
\text { covery and cough remission, and improves na- } \\
\text { sopharyngeal viral clearance }\end{array}$ & 109,110 \\
\hline Remdesivir & $\begin{array}{l}\text { Inhibition of viral } \\
\text { replication }\end{array}$ & $\begin{array}{l}\text { Shortens the recovery time in pregnant and } \\
\text { postpartum women with severe complications }\end{array}$ & $111-113$ \\
\hline $\begin{array}{l}\text { Corticoids, such as } \\
\text { dexamethasone }\end{array}$ & $\begin{array}{l}\text { Anti-inflammatory } \\
\text { actions }\end{array}$ & $\begin{array}{l}\text { Safe during pregnancy, reduces mortality and } \\
\text { promotes faster recovery from severe COVID- } \\
19 \text { pneumonia }\end{array}$ & 114,115 \\
\hline $\begin{array}{l}\text { Lopinavir and } \\
\text { Ritonavir }\end{array}$ & $\begin{array}{l}\text { 3-chymotrypsin-like } \\
\text { protease inhibitor }\end{array}$ & $\begin{array}{l}\text { Significantly reduces COVID- } 19 \text { mortality rates, } \\
\text { even among } \mathrm{HIV}^{+} \text {women }\end{array}$ & 116,117 \\
\hline
\end{tabular}

be transmitted during breastfeeding ${ }^{122}$. In a different study, Lackey et al. ${ }^{123}$ reviewed 13 studies examining the potential detection of COVID-19 in breast milk. They revealed that the COVID-19 specific IgG and the virus itself could be detected in milk, suggesting both are required for fetal immunity to COVID-19 to develop. Recovered mothers may volunteer to breastfeed other newborns to provide protection against this pandemic. The benefits of immunized breastfeeding may outweigh the potential risk of transmitting the viral RNA.

\section{CONCLUSION}

The present review investigated the impact of the COVID-19 pandemic on pregnancy, maternal and fetal health. Throughout this pandemic, pregnant women have had to ensure they follow the guidelines set out by organizations such as WHO, the Royal College of Obstetricians \& Gynaecologists and the American College of Obstetricians \& Gynecologists. Additionally, they have had to undergo frequent COVID19 testing to prevent any possible transmission of the disease. As a global pandemic, COVID-19 continues to expand and spontaneously mutate and develop. Therefore, there will be a continuous need for additional information on the impact of COVID19 on pregnant women, early-stage maternal women, and newborn infants. Many studies have confirmed the symptomatic, clinical, and physical pathogenicity of COVID-19. However, more genetic-based studies should be done to determine whether COVID19 has a genetic or epigenetic impact on pregnant women that may affect future generations. The need to safeguard the growing fetus during prenatal, labor, and delivery adds to the challenges that face obstetricians and gynecologists in managing this disease.
Despite the ability of SARS-CoV-2 to vertically transmit from infected mother to child and its presence in the breast milk of infected women, special precautions are always required to minimize the cross-infection of surrounding people, such as relatives, friends, and healthcare providers.

\section{ABBREVIATIONS}

ACE2: Angiotensin-converting enzyme 2

COVID-19: Coronavirus disease 2019

CT images: Computed Tomography images

H1N1: influenza A virus subtype H1N1 "Spanish flu" H2N2: Influenza A virus subtype H2N2 "Asian flu"

Ig G: Immunoglobulins G

Ig M: Immunoglobulins M

IL: Interleukin

MERS-CoV: Middle East Respiratory Syndromerelated Coronavirus

NK: Natural killer cells

RNA: Ribonucleic acid

RT-PCR: Reverse transcription polymerase chain reaction

SARS-CoV-2: Severe acute respiratory syndrome coronavirus 2

Th1: Type 1 T helper

Th2: Type 2 T helper

WHO: World Health Organization

\section{ACKNOWLEDGMENTS}

The authors would like to thank the collaboration between Management Science University Medical Centre, Universiti Sains Malaysia, Penang, Malaysia and Hospital Seberang Jaya that made this work possible.

\section{AUTHOR'S CONTRIBUTIONS}

All authors contributed equally to this work. All authors read and approved the final manuscript. 


\section{FUNDING}

None.

\section{AVAILABILITY OF DATA AND MATERIALS}

Not applicable.

\section{ETHICS APPROVAL AND CONSENT TO PARTICIPATE}

Not applicable.

\section{CONSENT FOR PUBLICATION}

Not applicable.

\section{COMPETING INTERESTS}

The authors declare that they have no competing interests.

\section{REFERENCES}

1. Lu H, Stratton CW, Tang YW. Outbreak of pneumonia of unknown etiology in Wuhan, China: the mystery and the miracle. J Med Virol. 2020;92(4):401-2. PMID: 31950516. Available from: $10.1002 / j m v .25678$.

2. Organization WH. WHO Director-General's remarks at the media briefing on 2019-nCoV on 11 February 2020. 2020.; 2020.

3. Bryan MS, Sun J, Jagai J, Horton DE, Montgomery A, Sargis $\mathrm{R}$, et al. Coronavirus disease 2019 (COVID-19) mortality and neighborhood characteristics in Chicago. Ann Epidemiol. 2020;(56):47-54. PMID: 33181262. Available from: 10.1016/j.annepidem.2020.10.011.

4. Organization WH. Clinical management of severe acute respiratory infection (SARI) when COVID-19 disease is suspected: interim guidance, 13 March 2020. World Health Organization; 2020.

5. Messina G, Polito R, Monda V, Cipolloni L, Nunno ND, Mizio GD. Functional role of dietary intervention to improve the outcome of COVID-19: a hypothesis of work. Int J Mol Sci. 2020;21(9):3104. PMID: 32354030. Available from: 10.3390/ ijms21093104.

6. Chen N, Zhou M, Dong X, Qu J, Gong F, Han Y. Epidemiological and clinical characteristics of 99 cases of 2019 novel coronavirus pneumonia in Wuhan, China: a descriptive study. Lancet. 2020;395(10223):507-13. PMID: 32007143. Available from: 10.1016/S0140-6736(20)30211-7.

7. Sun F, Matthews SA, Yang TC, Hu MH. A spatial analysis of the COVID-19 period prevalence in U.S. counties through June 28, 2020: where geography matters? . Ann Epidemiol. 2020;(52):54-59.e1. PMID: 32736059. Available from: 10. 1016/j.annepidem.2020.07.014.

8. Novel CPERE. The epidemiological characteristics of an outbreak of 2019 novel coronavirus diseases (COVID-19) in China. Zhonghua liu xing bing xue za zhi. 2020;41(2):145.

9. Bialek S, Boundy E, Bowen V, Chow N, Cohn A, Dowling $\mathrm{N}$, et al. Severe outcomes among patients with coronavirus disease 2019 (COVID-19)—United States, February 12-March 16, 2020. Morbidity and mortality weekly report. 2020;69(12):343-346. PMID: 32214079. Available from: 10.15585/mmwr.mm6912e2.

10. Karadag E. Increase in COVID-19 cases and case-fatality and case-recovery rates in Europe: A cross-temporal metaanalysis. J Med Virol. 2020;92(9):1511-7. PMID: 32437052. Available from: 10.1002/jmv.26035.

11. Schwartz DA. An analysis of 38 pregnant women with COVID-19, their newborn infants, and maternal-fetal transmission of SARS-CoV-2: maternal coronavirus infections and pregnancy outcomes. Arch Pathol Lab Med. 2020;144(7):799-805. PMID: 32180426. Available from: 10.5858/arpa.2020-0901-SA.

12. Qiao J. What are the risks of COVID-19 infection in pregnant women? Lancet. 2020;395(10226):760-2. PMID: 32151334. Available from: 10.1016/S0140-6736(20)30365-2.

13. Breslin N, Baptiste C, Gyamfi-Bannerman C, Miller R, Martinez R, Bernstein K. Coronavirus disease 2019 infection among asymptomatic and symptomatic pregnant women: two weeks of confirmed presentations to an affiliated pair of New York City hospitals. Am J Obstet Gynecol MFM. 2020;2(2):100118. PMID: 32292903. Available from: 10.1016/ j.ajogmf.2020.100118.

14. Gatta AND, Rizzo R, Pilu G, Simonazzi G. COVID19 during pregnancy: a systematic review of reported cases. Am J Obstet Gynecol. 2020;223(1):36-41. PMID: 32311350. Available from: 10.1016/j.ajog.2020.04.013.

15. Yahya EB, Alqadhi AM, Abdulsamad MA, Allaq AA. Asian Nipah virus and the potential of new pandemic. Pakistan Journal of Biotechnology. 2021;18(1):17-22. Available from: 10.34016/pjbt.2021.18.1.17.

16. Kain T, Fowler R. Preparing intensive care for the next pandemic influenza. Crit Care. 2019;23(1):337. PMID: 31665057. Available from: 10.1186/s13054-019-2616-1.

17. Liu YC, Kuo RL, Shih SR. COVID-19: the first documented coronavirus pandemic in history. Biomed J. 2020;43(4):32833. PMID: 32387617. Available from: 10.1016/j.bj.2020.04. 007.

18. Jamieson DJ, Theiler RN, Rasmussen SA. Emerging infections and pregnancy. Emerg Infect Dis. 2006;12(11):1638-43. PMID: 17283611. Available from: 10.3201/eid1211.060152.

19. Yassa M, Birol P, Mutlu AM, Tekin AB, Sandal K, Tug N. Lung Ultrasound Can Influence the Clinical Treatment of Pregnant Women With COVID-19. J Ultrasound Med. 2021;40(1):191203. PMID: 32478445 . Available from: 10.1002/jum.15367.

20. Yahya EB, Alqadhi AM. Recent trends in cancer therapy: A review on the current state of gene delivery. Life Sci. 2021;269:119087. PMID: 33476633. Available from: 10.1016/ j.lfs.2021.119087.

21. Velavan TP, Meyer CG. The COVID-19 epidemic. Trop Med Int Health. 2020;25(3):278-80. PMID: 32052514. Available from: $10.1111 /$ tmi.13383.

22. Cao X. COVID-19: immunopathology and its implications for therapy. Nat Rev Immunol. 2020;20(5):269-70. PMID: 32273594. Available from: 10.1038/s41577-020-0308-3.

23. Nicastri E, Petrosillo N, Bartoli TA, Lepore L, Mondi A, Palmieri $F$, et al. National institute for the infectious diseases " $L$. Spallanzani" IRCCS. Recommendations for COVID-19 clinical management. Infect Dis Rep. 2020;12(1):8543. PMID: 32218915. Available from: 10.4081/idr.2020.8543.

24. Li T, Lu H, Zhang W. Clinical observation and management of COVID-19 patients. Emerg Microbes Infect. 2020;9(1):68790. PMID: 32208840. Available from: 10.1080/22221751.2020. 1741327.

25. Yang Z, Wang M, Zhu Z, Liu Y. Coronavirus disease 2019 (COVID-19) and pregnancy: a systematic review. J Matern Fetal Neonatal Med. 2020;p. Online ahead of print. PMID: 32354293. Available from: 10.1080/14767058.2020.1759541.

26. Kasraeian M, Zare M, Vafaei H, Asadi N, Faraji A, Bazrafshan $\mathrm{K}$, et al. COVID-19 pneumonia and pregnancy; a systematic review and meta-analysis. J Matern Fetal Neonatal Med. 2020;p. Online ahead of print. PMID: 32429786. Available from: 10.1080/14767058.2020.1763952.

27. Karimi-Zarchi $M$, Neamatzadeh $H$, Dastgheib SA, Abbasi $H_{\text {, }}$ Mirjalili SR, Behforouz A. Vertical transmission of coronavirus disease 19 (COVID-19) from infected pregnant mothers to neonates: a review. Fetal Pediatr Pathol. 2020;39(3):24650. PMID: 32238084 . Available from: 10.1080/15513815.2020. 1747120. 
28. Sheth S, Shah N, Bhandari V. Outcomes in COVID-19 positive neonates and possibility of viral vertical transmission: a narrative review. Am J Perinatol. 2020;37(12):1208-16. PMID: 32736407. Available from: $10.1055 / \mathrm{s}-0040-1714719$.

29. Fornari F. Vertical transmission of Covid-19-a systematic review. Journal of Pediatrics. Perinatology and Child Health. 2020;4(2):7-13.

30. Ashraf MA, Keshavarz P, Hosseinpour P, Erfani A, Roshanshad A, Pourdast A. Coronavirus disease 2019 (COVID-19): a systematic review of pregnancy and the possibility of vertical transmission. J Reprod Infertil. 2020;21(3):157-68. PMID: 32685412.

31. Baral SD, Mishra S, Diouf D, Phanuphak N, Dowdy D. The public health response to COVID-19: balancing precaution and unintended consequences. Ann Epidemiol. 2020;46:12-3. PMID: 32532367 . Available from: 10.1016/j.annepidem.2020. 05.001 .

32. Pelton M. Efficacy of a Student-Led Community Contact Tracing Program Partnered with an Academic Medical Center during the COVID-19 Pandemic; 2020. Available from: 10. 1016/j.annepidem.2020.10.004.

33. Chen L, Li Q, Zheng D, Jiang H, Wei Y, Zou L. Clinical characteristics of pregnant women with Covid-19 in Wuhan, China. N Engl J Med. 2020;382(25):e100. PMID: 32302077. Available from: 10.1056/NEJMc2009226.

34. Huang C, Wang Y, Li X, Ren L, Zhao J, Hu Y. Clinical features of patients infected with 2019 novel coronavirus in Wuhan, China. Lancet. 2020;395(10223):497-506. PMID: 31986264. Available from: 10.1016/S0140-6736(20)30183-5.

35. Pan F, Yang L, Li Y, Liang B, Li L, Ye T. Factors associated with death outcome in patients with severe coronavirus disease-19 (COVID-19): a case-control study. Int J Med Sci. 2020;17(9):1281-92. PMID: 32547323. Available from: 10. 7150/ijms.46614.

36. Li N, Han L, Peng M, Lv Y, Ouyang Y, Liu K. Maternal and neonatal outcomes of pregnant women with coronavirus disease 2019 (COVID-19) pneumonia: a case-control study. Clin Infect Dis. 2020;71 (16):2035-41. PMID: 32249918. Available from: 10.1093/cid/ciaa352

37. Yang H, Sun G, Tang F, Peng M, Gao Y, Peng J. Clinical features and outcomes of pregnant women suspected of coronavirus disease 2019. J Infect. 2020;81(1):e40-4. PMID: 32294503. Available from: 10.1016/j.jinf.2020.04.003.

38. Gracia-Perez-Bonfils A, Martinez-Perez O, Llurba E, Chandraharan $\mathrm{E}$. Fetal heart rate changes on the cardiotocograph trace secondary to maternal COVID-19 infection. Eur J Obstet Gynecol Reprod Biol. 2020;252:286-93. PMID: 32645644. Available from: 10.1016/j.ejogrb.2020.06.049.

39. Millett GA, Jones AT, Benkeser D, Baral S, Mercer L, Beyrer C. Assessing differential impacts of COVID-19 on black communities. Ann Epidemiol. 2020;47:37-44. PMID: 32419766. Available from: 10.1016/j.annepidem.2020.05.003.

40. Zhu H, Wang L, Fang C, Peng S, Zhang L, Chang G. Clinical analysis of 10 neonates born to mothers with 2019nCoV pneumonia. Transl Pediatr. 2020;9(1):51-60. PMID: 32154135. Available from: $10.21037 /$ tp.2020.02.06.

41. Chen H, Guo J, Wang C, Luo F, Yu X, Zhang W. Clinical characteristics and intrauterine vertical transmission potential of COVID-19 infection in nine pregnant women: a retrospective review of medical records. Lancet. 2020;395(10226):809-15. PMID: 32151335. Available from: 10.1016/S0140-6736(20) 30360-3.

42. Allotey J, Stallings E, Bonet $\mathrm{M}$, Yap $\mathrm{M}$, Chatterjee $\mathrm{S}$, Kew $T$, et al. Clinical manifestations, risk factors, and maternal and perinatal outcomes of coronavirus disease 2019 in pregnancy: living systematic review and meta-analysis. Bmj. 2020;(370):m3320. Available from: 10.1136/bmj.m3320.

43. Baud D, Greub G, Favre G, Gengler C, Jaton K, Dubruc E. Second-trimester miscarriage in a pregnant woman with SARS-CoV-2 infection. JAMA. 2020;323(21):2198-200. PMID: 32352491. Available from: 10.1001/jama.2020.7233.
44. Hantoushzadeh S, Shamshirsaz AA, Aleyasin A, Seferovic MD, Aski SK, Arian SE, et al. Maternal death due to COVID-19. Am J Obstet Gynecol. 2020;223(1):109.e1-109.e16. PMID: 32360108. Available from: 10.1016/j.ajog.2020.04.030.

45. Blitz MJ, Rochelson B, Minkoff H, Meirowitz N, Prasannan L, London V. Maternal mortality among women with coronavirus disease 2019 admitted to the intensive care unit. Am J Obstet Gynecol. 2020;223(4). PMID: 32553910. Available from: 10.1016/j.ajog.2020.06.020.

46. Yan J, Guo J, Fan C, Juan J, Yu X, Li J, et al. Coronavirus disease 2019 in pregnant women: a report based on 116 cases. Am J Obstet Gynecol. 2020;223(1):111.e1-111.e14. PMID: 32335053. Available from: 10.1016/j.ajog.2020.04.014.

47. Sayeed SJ. Clinical, Laboratory Characteristics and Pregnancy Outcome of COVID-19 Patients Admitted in the Largest COVID Dedicated Hospital of Bangladesh. American Journal of Internal Medicine. 2021;9(1):11-6. Available from: 10.11648/j.ajim.20210901.12.

48. Elshafeey F, Magdi R, Hindi N, Elshebiny M, Farrag N, Mahdy S. A systematic scoping review of COVID-19 during pregnancy and childbirth. Int J Gynaecol Obstet. 2020;150(1):4752. PMID: 32330287 . Available from: 10.1002/ijgo.13182.

49. Savasi VM, Parisi F, Patanè L, Ferrazzi E, Frigerio L, Pellegrino A. Clinical findings and disease severity in hospitalized pregnant women with coronavirus disease 2019 (COVID-19). Obstet Gynecol. 2020;136(2):252-8. PMID: 32433453. Available from: 10.1097/AOG.0000000000003979.

50. Smith V, Seo D, Warty R, Payne O, Salih M, Chin KL. Maternal and neonatal outcomes associated with COVID-19 infection: A systematic review. PLoS One. 2020;15(6):e0234187. PMID: 32497090. Available from: 10.1371/journal.pone.0234187.

51. Capobianco G, Saderi L, Aliberti S, Mondoni M, Piana A, Dessole F. COVID-19 in pregnant women: A systematic review and meta-analysis. Eur J Obstet Gynecol Reprod Biol. 2020;252:543-58. PMID: 32713730. Available from: 10.1016/ j.ejogrb.2020.07.006.

52. Zaigham $M$, Andersson $O$. Maternal and perinatal outcomes with COVID-19: A systematic review of 108 pregnancies. Acta Obstet Gynecol Scand. 2020;99(7):823-9. PMID: 32259279. Available from: 10.1111 /aogs.13867.

53. Diriba K, Awulachew E, Getu E. The effect of coronavirus infection (SARS-CoV-2, MERS-CoV, and SARS-CoV) during pregnancy and the possibility of vertical maternal-fetal transmission: a systematic review and meta-analysis. Eur J Med Res. 2020;25(1):39. PMID: 32887660. Available from: 10.1186/ s40001-020-00439-w.

54. Woodward A. A pregnant mother infected with the coronavirus gave birth, and her baby tested positive 30 hours later. Business insider, India [online]. 2020 Mar. 2020;.

55. Schwartz DA, Graham AL. Potential maternal and infant outcomes from (Wuhan) coronavirus 2019-nCoV infecting pregnant women: lessons from SARS, MERS, and other human coronavirus infections. Viruses. 2020;12(2):194. PMID: 32050635. Available from: 10.3390/v12020194.

56. Dashraath P, Wong JL, Lim MX, Lim LM, Li S, Biswas A. Coronavirus disease 2019 (COVID-19) pandemic and pregnancy. Am J Obstet Gynecol. 2020;222(6):521-31. PMID: 32217113. Available from: 10.1016/j.ajog.2020.03.021.

57. Hecht JL, Quade B, Deshpande V, Mino-Kenudson M, Ting DT, Desai N. SARS-CoV-2 can infect the placenta and is not associated with specific placental histopathology: a series of 19 placentas from COVID-19-positive mothers. Mod Pathol. 2020;33(11):2092-103. PMID: 32741970. Available from: 10.1038/s41379-020-0639-4.

58. Baergen RN, Heller DS. Placental pathology in Covid-19 positive mothers: preliminary findings. Pediatr Dev Pathol. 2020;23(3):177-80. PMID: 32397896. Available from: 10 . $1177 / 1093526620925569$.

59. Richtmann R, Torloni MR, Otani ARO, Levi JE, Tobara MC de Almeida Silva C. Fetal deaths in pregnancies with SARSCoV-2 infection in Brazil: A case series. Case Rep Womens Health. 2020;27:e00243. PMID: 32704477. Available from: 
10.1016/j.crwh.2020.e00243.

60. Prajapat M, Sarma P, Shekhar N, Avti P, Sinha S, Kaur H. Drug targets for corona virus: A systematic review. Indian J Pharmacol. 2020;52(1):56-65. PMID: 32201449. Available from: 10.4103/ijp.IJP_115_20.

61. Coutard B, Valle C, de Lamballerie X, Canard B, Seidah NG, Decroly $E$. The spike glycoprotein of the new coronavirus 2019-nCoV contains a furin-like cleavage site absent in CoV of the same clade. Antiviral Res. 2020;176:104742. PMID: 32057769. Available from: 10.1016/j.antiviral.2020.104742.

62. Verma S, Carter EB, Mysorekar IU. SARS-CoV2 and pregnancy: an invisible enemy? Am J Reprod Immunol. 2020;84(5):e13308. PMID: 32678975. Available from: 10. 1111/aji.13308.

63. Narang K, Enninga EA, Gunaratne MD, Ibirogba ER, Trad AT, Elrefaei A, et al. SARS-CoV-2 infection and COVID-19 during pregnancy: a multidisciplinary review. InMayo Clinic Proceedings. 2020;95(8):1750-1765. Available from: 10.1016/j. mayocp.2020.05.011.

64. Yahya EB, Jummaat F, Amirul AA, Adnan AS, Olaiya NG, Abdullah CK. A review on revolutionary natural biopolymerbased aerogels for antibacterial delivery. Antibiotics (Basel). 2020;9(10):648. PMID: 32998197. Available from: 10.3390/ antibiotics 9100648 .

65. Bourgonje AR, Abdulle AE, Timens W, Hillebrands JL, Navis GJ, Gordijn SJ. Angiotensin-converting enzyme 2 (ACE2), SARS-CoV-2 and the pathophysiology of coronavirus disease 2019 (COVID-19). J Pathol. 2020;251(3):228-48. PMID: 32418199. Available from: 10.1002/path.5471.

66. West CA, Sasser JM, Baylis C. The enigma of continual plasma volume expansion in pregnancy: critical role of the reninangiotensin-aldosterone system. Am J Physiol Renal Physiol. 2016;311(6):1125-34. PMID: 27707703. Available from: 10.1152/ajprenal.00129.2016.

67. Garovic VD, White WM, Vaughan L, Saiki M, Parashuram S, Garcia-Valencia O. Incidence and long-term outcomes of hypertensive disorders of pregnancy. J Am Coll Cardiol. 2020;75(18):2323-34. PMID: 32381164. Available from: $10.1016 /$ j.jacc.2020.03.028

68. Glowacka I, Bertram S, Herzog P, Pfefferle S, Steffen I, Muench MO. Differential downregulation of ACE2 by the spike proteins of severe acute respiratory syndrome coronavirus and human coronavirus NL63. J Virol. 2010;84(2):1198-205. PMID: 19864379. Available from: 10.1128/JVI.01248-09.

69. Ferrario CM, Trask AJ, Jessup JA. Advances in biochemical and functional roles of angiotensin-converting enzyme 2 and angiotensin-(1-7) in regulation of cardiovascular function. Am J Physiol Heart Circ Physiol. 2005;289(6):2281-90. PMID: 16055515. Available from: 10.1152/ajpheart.00618. 2005.

70. Almashgab AM, Yahya EB, Banu A. The Cytotoxicity Effects of Outer Membrane Vesicles Isolated from Hospital and Laboratory Strains of Pseudomonas Aeruginosa on Human Keratinocyte Cell Line. Malays J Sci. 2020;39(3):45-53. Available from: $10.22452 / \mathrm{mj}$ s.vol39no3.3.

71. Areia AL, Mota-Pinto A. Can immunity during pregnancy influence SARS-CoV-2 infection? - A systematic review. J Reprod Immunol. 2020;142:103215. PMID: 33130538. Available from: 10.1016/j.jri.2020.103215.

72. Cattaneo M, Bertinato EM, Birocchi S, Brizio C, Malavolta D Manzoni M, et al. Pulmonary Embolism or Pulmonary Thrombosis in COVID-19? Is the Recommendation to Use HighDose Heparin for Thromboprophylaxis Justified? . Thromb Haemost. 2020;120(8):1230-1232. PMID: 32349132. Available from: 10.1055/s-0040-1712097.

73. Antoun L, Taweel NE, Ahmed I, Patni S, Honest H. Maternal COVID-19 infection, clinical characteristics, pregnancy, and neonatal outcome: A prospective cohort study. Eur J Obstet Gynecol Reprod Biol. 2020;252:559-62. PMID: 32732059. Available from: 10.1016/j.ejogrb.2020.07.008.

74. Yahya E. Insights into COVID-19 Chemotherapies: potential and Challenges. Journal of Chemistry and Nutritional
Biochemistry. 2021;2(1):1-12. Available from: 10.48185/jcnb. v2il.168.

75. Jummaat $F$, Yahya EB, S AKHP, Adnan AS, Alqadhi AM, Abdullah CK. The Role of Biopolymer-Based Materials in Obstetrics and Gynecology Applications: A Review. Polymers (Basel). 2021;13(4):633. PMID: 33672526. Available from: $10.3390 /$ polym 13040633 .

76. Phoswa WN, Khaliq OP. Is pregnancy a risk factor of COVID19? Eur J Obstet Gynecol Reprod Biol. 2020;252:605-9. PMID 32620513. Available from: 10.1016/j.ejogrb.2020.06.058.

77. Liu H, Wang LL, Zhao SJ, Kwak-Kim J, Mor G, Liao AH. Why are pregnant women susceptible to COVID-19? An immunological viewpoint. J Reprod Immunol. 2020;139:103122. PMID: 32244166. Available from: 10.1016/j.jri.2020.103122.

78. Hanna N, Hanna M, Sharma S. Is pregnancy an immunological contributor to severe or controlled COVID-19 disease? Am J Reprod Immunol. 2020;84(5):e13317. PMID: 32757366. Available from: 10.1111/aji.13317.

79. Sarapultsev A, Sarapultsev P. Immunological environment shifts during pregnancy may affect the risk of developing severe complications in COVID-19 patients. Am J Reprod Immunol. 2020;84(3):e13285. PMID: 32516444. Available from: 10.1111/aji.13285.

80. Wastnedge EA, Reynolds RM, van Boeckel SR, Stock SJ, Denison FC, Maybin JA. Pregnancy and COVID-19. Physiol Rev. 2021;101(1):303-18. PMID: 32969772. Available from: 10. 1152/physrev.00024.2020.

81. Tsafaras GP, Ntontsi $P$, Xanthou G. Advantages and limitations of the neonatal immune system. Front Pediatr. 2020;8:5. PMID: 32047730. Available from: 10.3389/fped. 2020.00005 .

82. Penfield CA, Brubaker SG, Limaye MA, Lighter J, Ratner AJ, Thomas KM. Detection of severe acute respiratory syndrome coronavirus 2 in placental and fetal membrane samples. Am J Obstet Gynecol MFM. 2020;2(3):100133. PMID: 32391518. Available from: 10.1016/j.ajogmf.2020.100133.

83. Peng $Z$, Wang J, Mo $Y$, Duan $W$, Xiang G, Yi M. Unlikely SARS-CoV-2 vertical transmission from mother to child: $A$ case report. J Infect Public Health. 2020;13(5):818-20. PMID: 32305459. Available from: 10.1016/j.jiph.2020.04.004.

84. Elkafrawi D, Joseph J, Schiattarella A, Rodriguez B, Sisti G. Intrauterine transmission of COVID-19 in Pregnancy: case report and review of literature. Acta Biomed. 2020;91(3):e2020041. PMID: 32921747.

85. Lamouroux A, Attie-Bitach T, Martinovic J, Leruez-Ville $M$, Ville $Y$. Evidence for and against vertical transmission for severe acute respiratory syndrome coronavirus 2 . Am J Obstet Gynecol. 2020;223(1):91.e1-91.e4. PMID: 32376317. Available from: 10.1016/j.ajog.2020.04.039.

86. Hascoët JM, Jellimann JM, Hartard C, Wittwer A, Jeulin $\mathrm{H}$, Franck P. Case Series of COVID-19 Asymptomatic Newborns With Possible Intrapartum Transmission of SARS-CoV2. Front Pediatr. 2020;8:568979. PMID: 33134230. Available from: 10.3389/fped.2020.568979.

87. Komine-Aizawa S, Takada K, Hayakawa S. Placental barrier against COVID-19. Placenta. 2020;99:45-9. PMID: 32755724. Available from: 10.1016/j.placenta.2020.07.022.

88. Blumberg DA, Underwood MA, Hedriana HL, Lakshminrusimha S. Vertical transmission of SARS-CoV-2: what is the optimal definition? Am J Perinatol. 2020;37(8):769-72. PMID: 32503058. Available from: 10.1055/s-0040-1712457.

89. Schwartz DA, Morotti D, Beigi B, Moshfegh F, Zafaranloo N Patanè $L$. Confirming vertical fetal infection with coronavirus disease 2019: neonatal and pathology criteria for early onset and transplacental transmission of severe acute respiratory syndrome coronavirus 2 from infected pregnant mothers. Arch Pathol Lab Med. 2020;144(12):1451-6. PMID: 32886737. Available from: 10.5858/arpa.2020-0442-SA.

90. Schwartz DA, Thomas KM. Characterizing COVID-19 maternal-fetal transmission and placental infection using comprehensive molecular pathology. EBioMedicine. 
2020;60:102983. PMID: 32980693. Available from: 10.1016/j. ebiom.2020.102983.

91. Elósegui JH. Does the maternal-fetal transmission of SARSCoV-2 occur during pregnancy?; 2020.

92. Mimouni F, Lakshminrusimha S, Pearlman SA, Raju T, Gallagher PG, Mendlovic J. Perinatal aspects on the covid-19 pandemic: a practical resource for perinatal-neonatal specialists. J Perinatol. 2020;40(5):820-6. PMID: 32277162. Available from: 10.1038/s41372-020-0665-6.

93. Zhang JJ, Lee KS, Ang LW, Leo YS, Young BE. Risk factors for severe disease and efficacy of treatment in patients infected with COVID-19: a systematic review, meta-analysis, and meta-regression analysis. Clin Infect Dis. 2020;71(16):2199206. PMID: 32407459 . Available from: $10.1093 / \mathrm{cid} /$ ciaa576.

94. Favre G, Pomar L, Musso D, Baud D. 2019-nCoV epidemic: what about pregnancies? Lancet. 2020;395(10224):e40. PMID: 32035511. Available from: 10.1016/S0140-6736(20) 30311-1.

95. Khan S, Peng L, Siddique R, Nabi G, Nawsherwan, Xue M. Impact of COVID-19 infection on pregnancy outcomes and the risk of maternal-to-neonatal intrapartum transmission of COVID-19 during natural birth. Infect Control Hosp Epidemiol. 2020;41(6):748-50. PMID: 32279693. Available from: 10.1017/ice.2020.84

96. Kc A, Gurung R, Kinney MV, Sunny AK, Moinuddin M, Basnet $O$. Effect of the COVID-19 pandemic response on intrapartum care, stillbirth, and neonatal mortality outcomes in Nepal: a prospective observational study. Lancet Glob Health. 2020;8(10):e1273-81. PMID: 32791117. Available from: 10.1016/S2214-109X(20)30345-4.

97. Taglauer E, Benarroch Y, Rop K, Barnett E, Sabharwal V, Yarrington $C$. Consistent localization of SARS-CoV-2 spike glycoprotein and ACE2 over TMPRSS2 predominance in placental villi of 15 COVID-19 positive maternal-fetal dyads. Placenta. 2020;100:69-74. PMID: 32862058. Available from: 10.1016/j.placenta.2020.08.015

98. Deniz M, Tezer H. Vertical transmission of SARS CoV-2: a systematic review. J Matern Fetal Neonatal Med. 2020;p. Online ahead of print. PMID: 32693656. Available from: 10.1080/14767058.2020.1793322.

99. Yang Z, Liu Y. Vertical transmission of severe acute respiratory syndrome coronavirus 2 : a systematic review. Am J Perinatol. 2020;37(10):1055-60. PMID: 32403141. Available from: 10.1055/s-0040-1712161.

100. Mulvey JJ, Magro CM, Ma LX, Nuovo GJ, Baergen RN. Analysis of complement deposition and viral RNA in placentas of COVID-19 patients. Ann Diagn Pathol. 2020;46:151530. PMID: 32387855 . Available from: 10.1016/j.anndiagpath. 2020.151530

101. Shanes ED, Mithal LB, Otero S, Azad HA, Miller ES, Goldstein JA. Placental Pathology in COVID-19. Am J Clin Pathol. 2020;154(1):23-32. PMID: 32441303. Available from: 10 1093/ajcp/aqaa089.

102. Rosenberg AZ, Yu W, Hill DA, Reyes CA, Schwartz DA. Placental pathology of Zika virus: viral infection of the placenta induces villous stromal macrophage (Hofbauer cell) proliferation and hyperplasia. Arch Pathol Lab Med. 2017;141(1):438. PMID: 27681334. Available from: 10.5858/arpa.2016-0401OA.

103. Ritter JM, Martines RB, Zaki SR. Zika virus: pathology from the pandemic. Arch Pathol Lab Med. 2017;141(1):49-59. PMID: 27704909. Available from: 10.5858/arpa.2016-0397-SA.

104. Allaq AA, et al. Epidemiological studies of the novel Coronavirus (COVID-19) in Libya. Pak J Biotechnology. 2021;18(1):7-16. Available from: 10.34016/pjbt.2021.18.1.7.

105. Ali A, Rashid Z, Zhou J, Yousaf MZ, Galani S, Ashraf A. Evaluating antibody response pattern in asymptomatic virus infected pregnant females: human well-being study. J King Saud Univ Sci. 2021;33(1):101255. PMID: 33288976. Available from: $10.1016 /$ j.jksus.2020.101255.

106. Ai T, Yang Z, Hou H, Zhan C, Chen C, Lv W. Correlation of chest CT and RT-PCR testing for coronavirus disease 2019
(COVID-19) in China: a report of 1014 cases. Radiology. 2020;296(2):32-40. PMID: 32101510. Available from: 10. 1148/radiol.2020200642.

107. Zhang W, Du RH, Li B, Zheng XS, Yang XL, Hu B. Molecular and serological investigation of 2019-nCoV infected patients: implication of multiple shedding routes. Emerg Microbes Infect. 2020;9(1):386-9. PMID: 32065057. Available from: 10.1080/22221751.2020.1729071.

108. Donders F, Lonnée-Hoffmann R, Tsiakalos A, Mendling W, de Oliveira JM, Judlin $P$, et al. ISIDOG recommendations concerning COVID-19 and pregnancy. Diagnostics (Basel). 2020;10(4):243. PMID: 32338645. Available from: 10.3390/ diagnostics 10040243 .

109. Prayuenyong P, Kasbekar AV, Baguley DM. Clinical implications of chloroquine and hydroxychloroquine ototoxicity for COVID-19 treatment: a mini-review. Front Public Health. 2020;8:252. PMID: 32574312 . Available from: 10.3389/fpubh. 2020.00252.

110. Taylor MM. Inclusion of pregnant women in COVID-19 treatment trials: a review and global call to action; 2020.

111. Beigel JH, Tomashek KM, Dodd LE, Mehta AK, Zingman BS, Kalil AC, et al. Remdesivir for the treatment of Covid-19. N Engl J Med. 2020;383(19):1813-26. PMID: 32445440. Available from: 10.1056/NEJMoa2007764.

112. Burwick RM, Yawetz S, Stephenson KE, Collier AR, Sen $P$ Blackburn BG, et al. Compassionate Use of Remdesivir in Pregnant Women with Severe Covid-19. Clin Infect Dis. 2020;p. Online ahead of print. PMID: 33031500 . Available from: $10.1093 / \mathrm{cid} / \mathrm{ciaa} 1466$.

113. Igbinosa I, Miller S, Bianco K, Nelson J, Kappagoda S, Blackburn BG. Use of remdesivir for pregnant patients with severe novel coronavirus disease 2019. Am J Obstet Gynecol. 2020;223(5):768-70. PMID: 32771381. Available from: 10 1016/j.ajog.2020.08.001.

114. Horby $\mathrm{P}$, Landrain M. Low-cost dexamethasone reduces death by up to one third in hospitalised patients with severe respiratory complications of COVID-19 [Internet]. RECOVERY trial, 2020; 2020.

115. Group RC. Dexamethasone in Hospitalized Patients with Covid-19 . N Engl J Med. 2021;384(8):693-704. PMID: 32678530. Available from: 10.1056/NEJMoa2021436.

116. Bhatnagar T, Murhekar MV, Soneja M, Gupta N, Giri S, Wig N. Lopinavir/ritonavir combination therapy amongst symptomatic coronavirus disease 2019 patients in India: protocol for restricted public health emergency use. Indian $J$ Med Res. 2020;151 (2 \{\&amp;\} 3):184-9. PMID: 32362644.

117. Hung IF, Lung KC, Tso EY, Liu R, Chung TW, Chu MY. Triple combination of interferon beta- $1 \mathrm{~b}$, lopinavir-ritonavir, and ribavirin in the treatment of patients admitted to hospital with COVID-19: an open-label, randomised, phase 2 trial. Lancet. 2020;395(10238):1695-704. PMID: 32401715. Available from: 10.1016/S0140-6736(20)31042-4.

118. Salem D, Katranji F, Bakdash T. COVID-19 infection in pregnant women: Review of maternal and fetal outcomes. Int J Gynaecol Obstet. 2020;152(3):291-298. PMID: 33305352. Available from: 10.1002/ijgo.13533.

119. Parra-Bracamonte GM, Lopez-Villalobos N, ParraBracamonte FE. Clinical characteristics and risk factors for mortality of patients with COVID-19 in a large data set from Mexico . Ann Epidemiol. 2020;(52):93-98.e2. PMID: 32798701. Available from: 10.1016/j.annepidem.2020.08.005.

120. Organization WH. Coronavirus disease 2019 (COVID-19): situation report, 82. 2020.

121. Ortiz El, Herrera E, Torre ADL. Coronavirus (COVID 19) Infection in Pregnancy. Colomb Med (Cali). 2020;51(2):e4271. PMID: 33012886

122. Grob R, Conzelmann C, Müller JA, Stenger S, Steinhart $K$, Kirchhoff $\mathrm{F}$, et al. Detection of SARS-CoV- 2 in human breastmilk. Lancet. 2020;395(10239):1757-8. PMID: 32446324. Available from: 10.1016/S0140-6736(20)31181-8. 
123. Lackey KA, Pace RM, Williams JE, Bode L, Donovan SM, Järvinen KM. SARS-CoV-2 and human milk: what is the evidence?
Matern Child Nutr. 2020;16(4):e13032. PMID: 32472745 Available from: $10.1111 / \mathrm{mcn} .13032$. 
Ready to submit your manuscript? Choose Biomedpress and benefit from:

- Fast, convenient online submission

- Through peer-review by experienced researchers

- Rapid publication on acceptance

- Free of charge (without publication fees)

Learn more http://www.biomedpress.org/journals/
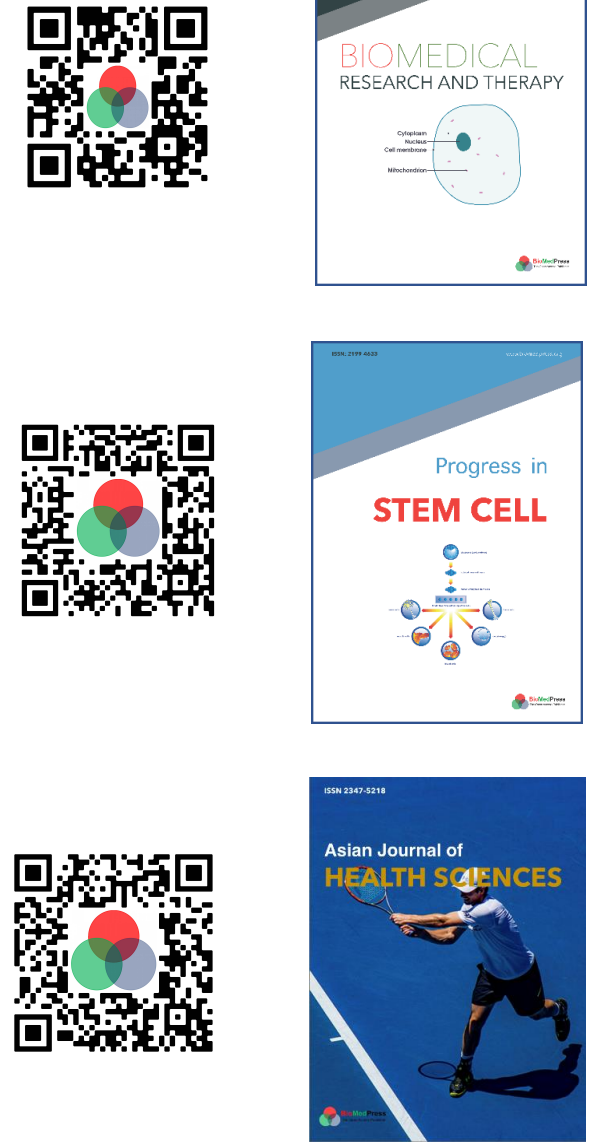

Asian Journal of Health Sciences

ISSN: 2347-5218

Indexed: Google Scholar

Acceptance Rate (2020): 72.89\%

Article Publishing Charge: Free

Submission to first editorial decision: 16.5 days

Biotechnological Research

ISSN: 2395-6763

Indexed: Google Scholar

Acceptance Rate (2020): $67.02 \%$

Article Publishing Charge: Free

Submission to first editorial decision: 28.5 days 